\title{
Life Cycle Analyses of PV Solar Systems: Nowadays, Forecast, Process and Replacements
}

\author{
Nuno Domingues* \\ ISEL-ADEM, Rua Conselheiro Emidio Navarro, Portugal
}

Submission: July 17, 2020; Published: September 17, 2020

*Corresponding author: Nuno Domingues, ISEL-ADEM, Rua Conselheiro Emidio Navarro, Portugal

\begin{abstract}
Taking advantage of the technology's fiercely improved competitiveness in Solar Power, Portugal is investing solid in this type of technology. Solar energy has been presented as a key solution for satisfying the energy demand with environmental and social benefits. Being true on energy production (electricity and thermal), on the remaining life cycle one can find evidences far from it. The electric components of a PV panel are still based on rare elements, such as Silicium. The manufacturing the Solar panels requires cooper, iron, steel and other metals. The electricity by PV production obliges the use of storage devices, mainly batteries, that uses elements dangerous for the environment, such as acids. Also, modern batteries are based on rare elements, such as lithium. The exploration of raw materials, such as silicium and lithium, is very controversial because of the local social impacts on agriculture, forestry, and landscape of rural areas, for example.
\end{abstract}

The present paper presents the different principal technologies on market (monocrystalline, polycrystalline and thin film), the necessary devices (load regulator, protections, e.g.), the common devices (such as storage devices and backup systems), and focus on their materials impact, based on a life-cycle analyses. The present paper also presents the process of full recycling a PV solar system. It is possible to realize that, despite the high energy impact and environmental impact in mining and manufacturing, the PV solar systems fully compensate in the short run. Thereby, there is not only the economic advantage.

Keywords: Life cycle analyses; Environmental impact; Recycling; Waste management; Solar PV panels; DC cables; Inverter

\section{Introduction}

Around the world, 2018 brought the PV industry many ups and downs, policy shift, tariffs, cancellations and lack of clarity about the future of solar PV with or without storage. The industry's extreme uncertainty had impacted every section of the
PV supply chain. Global solar PV installations will reach a new high of $114.5 \mathrm{GW}$ by the end of 2019 , up $17.5 \%$ on 2018 . The market is now back on a strong growth trajectory after a slowdown in 2018. Annual installations are expected to rise to around $125 \mathrm{GW}$ per year by the early 2020s (Figure 1).

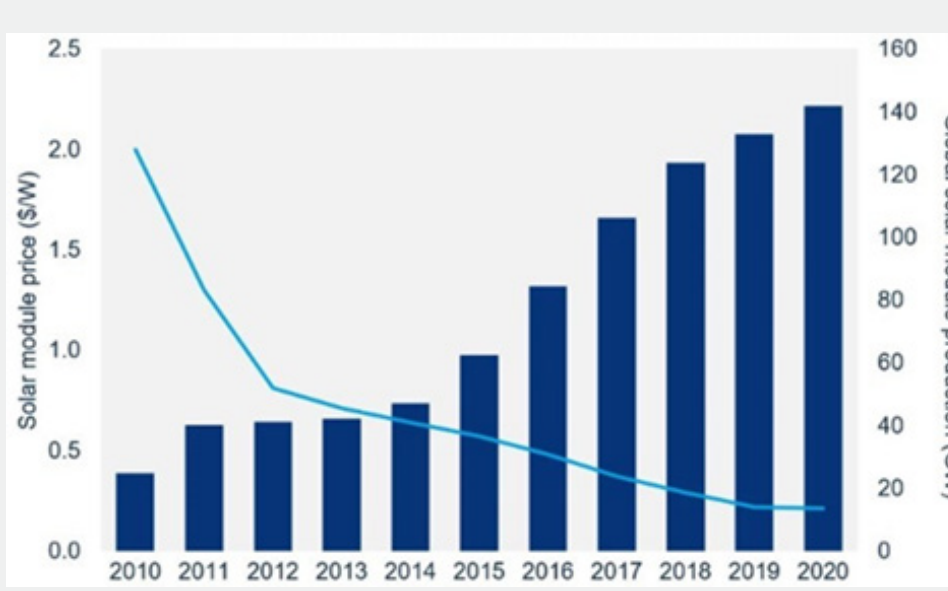

Figure 1: Shows Annual Solar PV Demand by Major Region for the Period 2015-2024 [1]. 
Technological innovations will reduce the cost of electricity (LCOE) by source in the next decade. Since 2010, prices for photovoltaic solar panels have dropped by approximately $90 \%$, an incredible reduction that makes this technology attractive. Figure 2 [1] shows the evolution of the prices of photovoltaic solar panels. It was in 2010 that solar energy grew at a giant pace. In the last decade alone, solar installations worldwide have grown more than 6 times, from 16GW in 2010 to $105 \mathrm{GW}$ in 2019 (annual values). Meanwhile, prices for silicon solar panels have dropped from just over $€ 2$ / W to just over $€ 0.20$ / W in the third quarter of 2019! A price reduction of around $90 \%$ has become one of the most important factors driving the worldwide expansion of solar energy. No other electricity generation technology has been able to keep up with this pace of reducing solar energy costs during this period.

Figure 2: Annual solar PV demand by major region, 2015-2024.

Decade of 2010 witnessed the following improvements in solar panels: More efficient monocrystalline silicon panels began to replace polycrystalline silicon panels, becoming the predominant panels. Solar panels began to use advanced cell architectures, such as the passive emitter and posterior contact (PERC) and interdigital posterior contact (IBC), the straight union with an intrinsic thin layer and double-sided cell technologies. Panels based on larger cells (158mm and above) and N-type cells begin to dominate the market. Innovative panel techniques, such as medium-cut panels and solar tiles, are starting to have their market share.

China and the United States, as leaders in the solar sector, will need to build recycling plants or find an alternative way to deal with this waste. Figure 3 [3] shows the cumulative waste volumes of the leading countries in solar installations and the volume of end-of-life waste by 2050. [2] analysis has detected a variety of developments and some thoughts on the top 10 trends to watch this year:

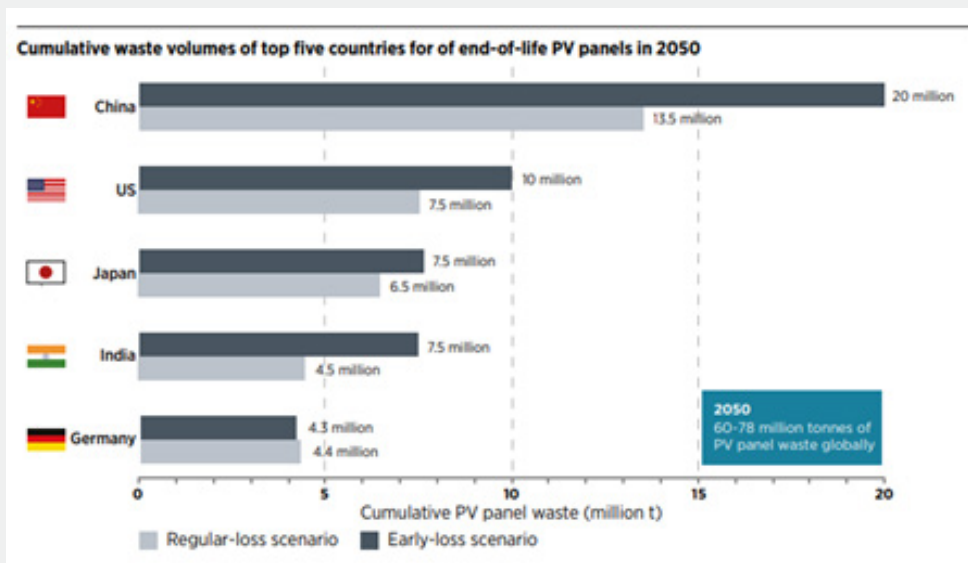

Figure 3: Cumulative waste Volumes of the Leading Countries in Solar installations and the Volume of end-of-life waste by 2050.

a) The market will (finally) crack $100 \mathrm{GW}$ for the first time b) More sub-\$30/MWh bids-and maybe even another record low 
c) Revised policy targets will determine the market's longterm growth

d) Another entrant to the subsidy-free club in Europe.

e) Big business goes big on corporate solar procurement in the U.S.

f) More projects trading hands, particularly in the U.S.

g) Large-scale solar-plus-storage comes into the spotlight but remains a niche solution in emerging markets.

h) Mono PERC and bifacial modules keep CapEx costs marching down.

i) A make-or-break year for mega-project plans.

j) Oil and gas majors embrace solar in upstream and power.

The point 4 (Another entrant to the subsidy-free club in
Europe) refers to Spain, Portugal, and Italy have been at the vanguard of subsidy-free utility-scale solar PV, with multiple gigawatts in the development pipeline. This year will see the first wave of those projects delivered. As costs continue to come down, 2019 is also set to be the year that the trend spreads beyond Southern Europe. In the UK, there has been no support scheme available for large-scale solar PV since the Renewables Obligation closed in the first quarter of 2017. Nevertheless, there are projects of $2.3 \mathrm{GW}$ that either already have or are awaiting planning permission in the development pipeline that could be delivered without subsidy. This is of special importance for Portugal in the short run subject to energy production in terms of energy and in the long run for waste management in terms of recycling. The renewable energy new investments are shown in Figure 4. [4] It is possible to observe that solar energy has the major new investments, followed by close by small hydro.

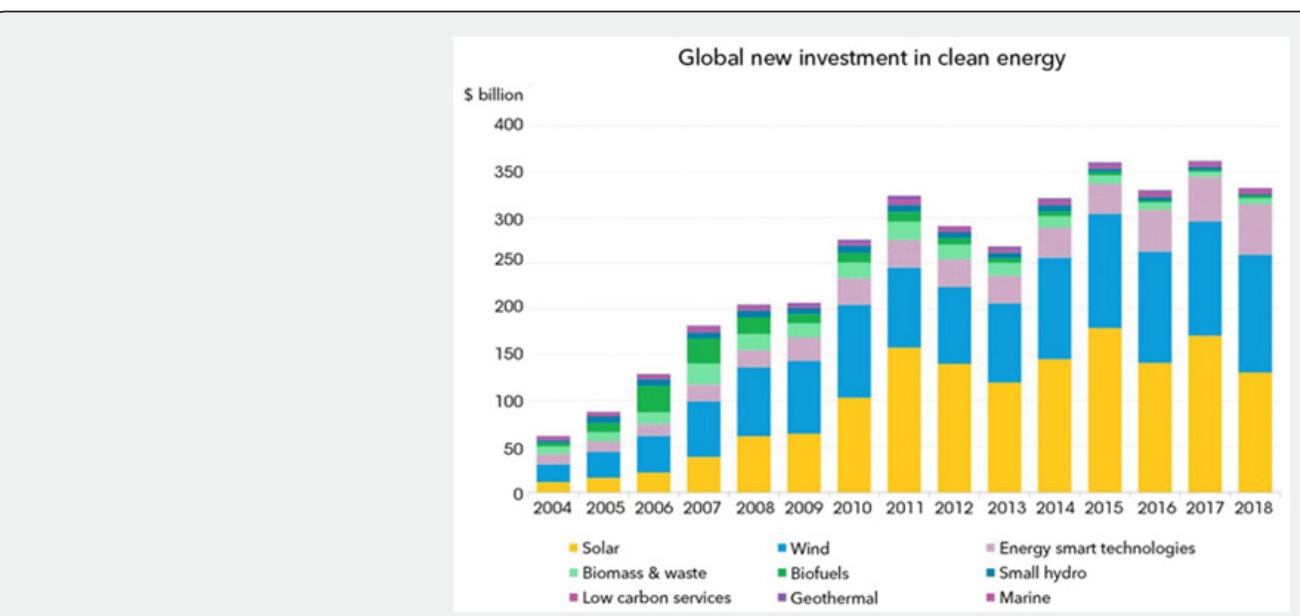

Figure 4: Renewable Energy new Investments by Technology.

Figure 5 [5] shows the past investments by Country groups. It is possible to observe that the total investment in solar power was down almost a quarter in 2017, partly due to changes in Chinese solar policy, which restricted new projects' access to the feed-in tariff.

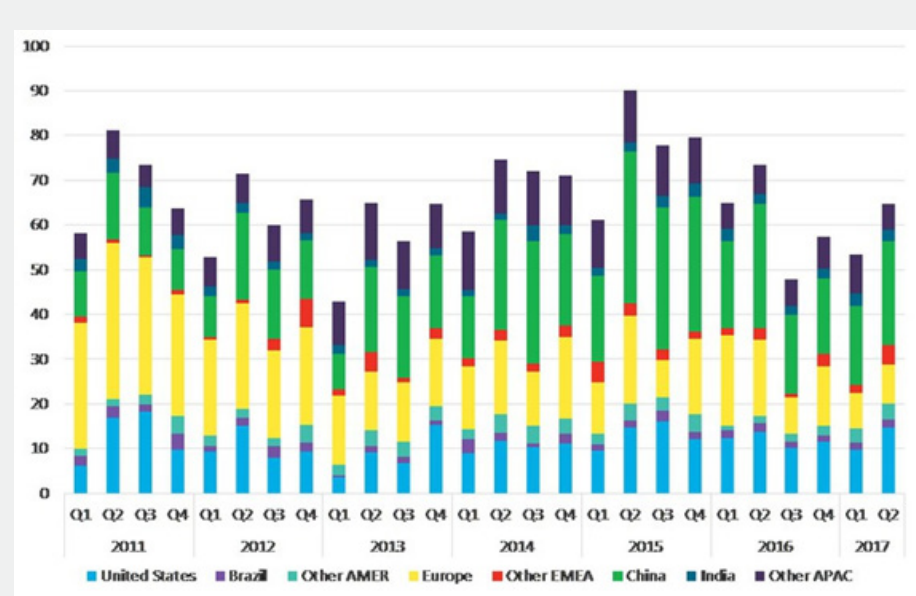

Figure 5: Past Investments in Solar PV. 


\section{Solar Technologies}

Energy Trend believes that the PV industry has faced several critical challenges as well as reshufflings in 2018. In the face of these developments, the industry is expected to become healthier and more stable in the long run. As the supply chain's prices continue to decline, the PV industry is expected to approach grid parity with fewer subsidies. The popularity of non-subsidized systems and the actual uniform power cost (LCOE) will become the price indicators for supply chains in the future. Further price decline expected and sales increase.

Although the whole PV supply chain suffered from low margin and oversupply in 2018, the Rank companies still reported strong operating results driven by their advanced technologies, competitive cost structure and wide global distributions. Most of their capacity expansion plans can still be put into practice. Because of that, the upstream sectors have continuously become more concentrated and Mono-Si wafers to be the mainstream supply. With mono-Si wafers becoming mainstream and taking up to $60 \%$ of the annual wafer supply in 2019 , their supply chain will play a more dominant role in the market. It will also reverse the situation that multi-Si products are more competitive than mono-Si ones in recent years, and multi-Si manufacturers with less market competitiveness will gradually be eliminated in the future. For decades thin film modules have struggled to grow or even maintain market share, however, new approaches to largearea module production and other advances show that thin film is gaining ground on its inherently superior cost and performance profiles.

Thin solar panels use solar cells produced from Cadmium
Telluride, a compound that makes them flexible, light and environmentally friendly. As they have a flexible feature, and because they are thin, they have several applications. In terms of value, they are cheaper than poly or mono solar modules, but with an efficiency of only $16 \%$. Ideal for outdoor activities as they allow you to charge mobile phones or tablets. Polycrystalline solar panels use polycrystalline silicon solar cells, which are cheaper than monocrystalline silicon cells. They have a better efficiency when compared to thin solar panels, about $17 \%$, but being a fixed solar module, it cannot walk from one side to the other. Monocrystalline solar panels are produced from high purity silicone, which is cut into pieces and then used to create a highly efficient solar module. Panasonic currently offers solar panels with an efficiency of $19.7 \%$, with solar cells of $21.7 \%$ efficiency. Double-sided solar panels can provide a bonus between $5 \%$ to $15 \%$ of the output power with only a price premium of $2 \%$ to $3 \%$. Because fewer solar panels will be used to produce the same amount of electricity, double-sided panels can reduce system balance (BoS) costs by $3 \%$ to $7 \%$. [7-10].

\section{How fast do solar panels degrade/lose their efficiency?}

Solar panel manufacturers put a lot of effort into making their solar panels robust. They need to be able to withstand heat/cold cycles and heavy weather. However, solar panels are not flawless, and they will inevitably age. The rated power output of solar panels typically degrades at about $0.5 \%$ /year. However, thin-film solar panels (a-Si, CdTe and CIGS) degrades faster than panels that are based on mono- and polycrystalline solar panels. Table 1 [11] shows the output loss in percentage per year, where Pre and Post refer to installations prior to and post 2000.

Table 1: Output loss in percent per year.

\begin{tabular}{|c|c|c|}
\hline \multirow{2}{*}{ Solar cell type } & \multicolumn{2}{|c|}{ Output loss in percent per year } \\
\cline { 2 - 3 } & Pre & Post \\
\hline Amorphous silicon (a-Si) & 0.96 & 0.87 \\
\hline Cadmium telluride (CdTe) & 3.33 & 0.4 \\
\hline Copper indium gallium selenide (CIGS) & 1.44 & 0.96 \\
\hline Monocrystalline silicon (mono-Si) & 0.47 & 0.36 \\
\hline Polycrystalline silicon (poly-Si) & 0.61 & 0.64 \\
\hline
\end{tabular}

Solar panels typically degrade faster in the first couple of years of their life. It is difficult to precise the life expectancy of solar panels and the real Lifecycle of Solar Panels. However, one can find interesting to associate it to the warranties given by the manufacturers. Figure 6 [12] shows different solar panel warranties on the market nowadays for different manufacturers based on the guarantee that the performance of their solar panels will stay above the presented ranges. Most manufacturers offer the 25-year standard solar panel warranty, which means that power output should not be less than $80 \%$ of rated power after 25 years. So, the question that raises is what will happen to solar panels after those 25 years? The truth is one doesn 't really know since there is not really a lot of data to look at since photovoltaics is a relatively new technology (most of all solar panels are less than 10 years old). What can one do to extend the life of my solar panels?

a) Avoid physical damage (e.g. trees and bushes blowing in the wind and creating scratches). The more surface scratches, the more performance degradation. In the worst-case, water can seep through the surface, which can short-circuit the solar panels.

b) Regular maintenance and cleaning are important. 
c) The more weather and wind the solar panels are exposed

wind when evaluating placement). to, the faster they will degrade (e.g. think about shelter from the

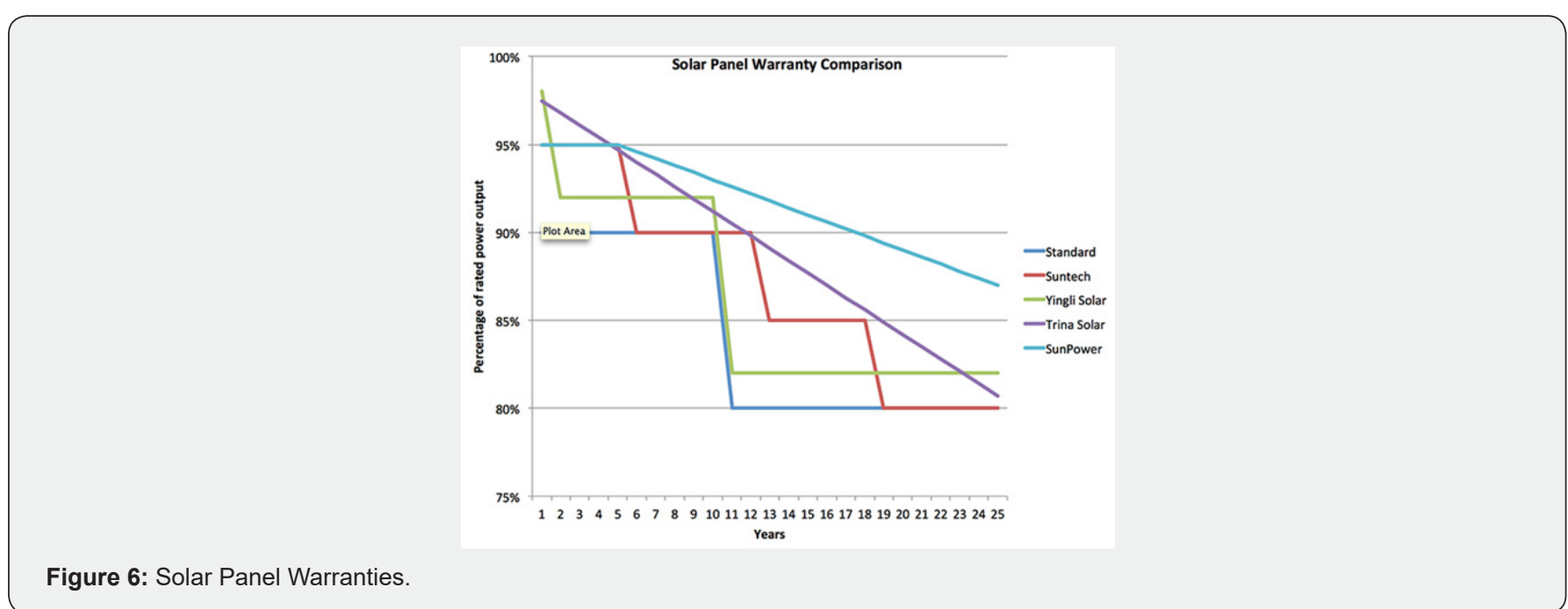

With the rapid growth of solar energy in recent years, some concerns are raised, such as the analysis of the life cycle of photovoltaic panels and their useful life.

a) After reaching their time limit, can they be recycled or reused?

b) How much energy does a photovoltaic system need in its production?

c) And how much $\mathrm{CO} 2$ is released into the environment for its production? [13]

\section{LCA- life cycle assessment}

A life cycle assessment (LCA - also called a 'life cycle analysis') examines every aspect of a product's life from the gathering of raw materials right up to its disposal and eventual breakdown. Life cycle analysis is a technique for measuring the environmental impacts associated with a product's life stages from raw material extraction, production, distribution, use, final disposal, and recycling. This involves the amount of material and energy required by all these steps in addition to the emission of pollutants and waste during use. Even environmentally 'friendly' technologies like solar panels have some impact on the environment, and it is well worth considering how much energy goes into their manufacture. A proper LCA will by necessity be as specific as possible to measure the total influence of the product, especially considering things like how and where materials and components are produced, and what sorts of emissions are associated with transport.

First the quartzite is mined and refined into silicon, then further processed to make a silicon cell. Components are then assembled and shipped in bulk around the world to individual retailers. From there, the products are purchased and installed in people's homes where they will begin to pay back the energy used in their production. At the end of their lives - normally somewhere between 25 and 30 years, some components may be recycled, reversing any energy used in the initial gathering and others will need to be scrapped. In addition to the cell itself, glass for the covering, aluminium for the framing and copper for the wiring as well as various rubbers and plastics all go into making the completed kit. Nearly all the energy 'consumed' across a solar panel setup's life cycle (close to 85\%) comes from turning the quartzite rock into a silicon wafer. More specifically, about half of this energy is consumed turning the silicon from metallurgic grade silicon (MG-Si) into a refined solar-grade silicon (SoG-Si) required in solar cells.

As well as the solar panels themselves, a complete assessment also needs to consider other supporting hardware like DC to AC inverters. The amount of energy used in the production of a $1 \mathrm{~kW}$ solar PV system creates nearly two tonnes of greenhouse gases. The next largest contributor to energy use is the production of the inverter, but at only around $7 \%$ of the total, it pales in comparison to the production of the solar panels. Batteries and inverters typically must be replaced every 5 to 10 years. Solar panels are relatively quick to generate enough energy to offset the amount used in their own production, so they are quite efficient.

The European Union was the first world body to adopt specific laws for future solar panel waste. The European directive included specific objectives for the collection and recycling of solar panels and obliges all producers to finance the costs of this collection. This Directive introduced the legal obligation to recycle photovoltaic panels, across Europe. In Portugal, the transposition of the directive into the national legislative framework attributed 
this responsibility to producers of this type of equipment, as of 8 May 2014 (Decree-Law No. 67/2014, of 7 May). [14-22].

\section{Recycling process}

The International Renewable Energy Agency (IRENA) carried out a study and published in 2015, a report that says that the volumes of photovoltaic panel waste in 2050 could be worth millions of euros in the world market for basic products, whenever appropriate recycling is done and the materials are reused. For example, the project CABRISS of Horizonte 2020 [23] that was launched in July 2015 showed that it is possible to use three main techniques to extract reusable materials of high value and efficiency from recycled panels:

a) A process to remove the blade and to recover recyclable materials such as silver, silicon and high purity glass with thin photovoltaic film at the end of its useful life and photovoltaic module

b) A technique for the recovery of solid waste from solar manufacturing

c) It is a kerf process for drying photovoltaic silicon waste from material lost during the cutting process.

To identify the component characterization some steps are made. The first part to remove from the different types of components present in the modules is the frame, which is easily removed manually. All the material can be fully recycle. The glass layer present in the modules is thus easily accessible to be removed manually and is then comminated in an aluminum mortar. After comminution, the powder is sieved through a sieve and sent for X-ray fluorescence analysis.

The photovoltaic cells present in the modules are coated with different polymeric materials, so a process using solvents is required to remove the material. Preliminary tests are carried out with several types of solvents (Hydrofluoric Acid, Sulfuric Acid, Alcohol, Acetone and a solution mentioned in the literature containing $300 \mathrm{ml}$ of $\mathrm{HF} 40 \% \mathrm{PA}, 30 \mathrm{ml}$ of $\mathrm{HNO}_{3} 65 \% \mathrm{PA}, 90 \mathrm{ml}$ of $\mathrm{H}_{2} \mathrm{O}$ DI and $3 \mathrm{~g}$ of $\mathrm{NH}_{4} \mathrm{~F}(65)$ ). There are two procedures that best detach the cell from the module:

a) Pieces of about $1 \mathrm{~cm}^{2}$ are dipped in HF $40 \%$ P.A. and left for 48 hours. The glass of these pieces is previously removed manually. This immersion resulted in the precipitation of small amounts of a black coloured powder. This procedure is repeated until approximately $10 \mathrm{~g}$ of material is obtained. Then, the solution was filtered by gravity on $45 \mu \mathrm{m}$ filter paper. The filtered material was washed with distilled water, dried in an oven at $100^{\circ} \mathrm{C}$ and ground in an aluminum mortar, for further analysis by X-ray diffraction and fluorescence.

b) For encapsulating material of the module with greater surface area (rough), pieces with about $2 \mathrm{~cm}^{2}$ were dipped in PA sulfuric acid and left for 48 hours, subjected to constant magnetic stirring to facilitate the removal of silicon. There is no prior separation of the module glass. Once the desired material has precipitated, the solution is filtered by gravity on $45 \mu \mathrm{m}$ filter paper. The filtered material is washed with distilled water, dried in an oven at $100^{\circ} \mathrm{C}$ and ground in an aluminum mortar, for further analysis by X-ray diffraction and fluorescence. The final material consists of a fine black powder. The material is sieved, so that the particles had a size less than or equal to $0.044 \mathrm{~mm}$. This material was analyzed by X-ray diffraction and X-ray fluorescence. $\mathrm{X}$-ray diffraction analysis can be performed on a diffractometer employing $\mathrm{Cu}-\mathrm{K} \alpha$ radiation, $\theta-\theta$ goniometer (theta-theta) and graphite monochromator at the detector entrance.

In order to better analyze the constitution of the photovoltaic cell, a sample of module A is taken to the optical microscope. To do this, the front glass layer and the adhesive layer of a $2 \mathrm{~cm}^{2}$ sample from the module are manually removed. The metallic filaments present in the modules are the following elements: Copper, lead and tin. The Silver Concentration / Extraction processes start with the segregation of the materials present in order to allow the proposition of a recycling route. Grinding, granulometric separation, leaching, precipitation and thermal process (pyrolysis) procedures are used. Initially, grinding is carried out together in knife mills in order to make a comminution of all parts without any prior separation (except for the external aluminum frames). The modules pass through a knife mill several times with different opening grids. After the grinding step, a granulometric separation is made using a sieve on a sieve shaker, obtaining three different fractions: smaller $(<0.5 \mathrm{~mm})$, intermediate $(0.5 \mathrm{~mm}<\mathrm{n}<1 \mathrm{~mm})$ and larger $(>1,0 \mathrm{~mm})$, then being digested in a 3:1 solution of aqua regia ( 3 parts of $38 \%$ hydrochloric acid to 1 part of $64 \%$ nitric acid), with stirring. There is a risk of precipitation of silver chloride but using aqua regia is a common solution in works for the characterization of metals in waste electrical and electronic equipment. In order to concentrate the silver identified in the photovoltaic cell, leaching with nitric acid is carried out. Digestion takes place at room temperature for two hours, under magnetic stirring. The solution is filtered, the precipitate is reserved. The filtered solution was analyzed via atomic absorption spectrometry (AA) to quantify the silver in solution. The amount of sodium chloride $(\mathrm{NaCl})$ to be added can be determined empirically by making the addition in two steps and observing precipitation. If precipitation does not occur in the second step, it appears that all ionic silver reacted with the chloride. Thus, $1.5 \mathrm{~g}$ of $\mathrm{NaCl}$ is added to the filtered solution to precipitate silver in the form of Silver Chloride (AgCl).

The main difficulty encountered in separating the components is due to the polymeric adhesive material that joins the glass layer and the semiconductor layer (cell). Even when the glass layer is removed manually, the polymeric adhesive remains attached to the semiconductor layer. Therefore, the idea of using a previous pyrolysis aims at removing this adhesive layer beforehand to facilitate a later concentration of silver. [24-29]. 


\section{Conclusion}

Technological innovations, lower prices, widespread market opportunities and small-scale investments lead to a massive introduction of PV solar systems and forecasted to grow exponentially. This amazing primary energy is not neutral, and the life cycle is required to be considered.

a) It is possible to conclude that solar PV full cycle proves that the environmental impact and cost of these technologies is low. Also, the recycling process is quite simple and low-cost. Although the solar PV systems are not neutral, the environmental impact allied with the energy and economic benefits are a boost for this primary energy osn the mix.

\section{References}

1. Evolution of prices for solar modules Vs Global manufacturing capacity.

2. Wood Mackenzie (2020) Global solar PV market outlook update.

3. IRENA (2016) End-of-life management: solar photovoltaic panels. report, June.

4. Bloomberg NEF (2019).

5. Source: Bloomberg NEF.

6. Windpower Monthly.

7. https://www.pveurope.eu/News/Markets-Money/50-solar-growthpredicted- in- Europe- for 2019? utm_ source = newsletter\&utm medium =email\&utm _ campaign $=20190118 \_50 \% 25+$ solar+growth + in + Europe + predicted $\% 2 \mathrm{C}+$ subsidy + free + sola.

8. https://www.pveurope.eu/News/Markets-Money/EMEA-regionwith-strongest-solar-growth-globally.

9. https://www.pveurope.eu/News/Solar-Generator/123-GW-PVinstallations-expected-in-2019.

10. https://www.pveurope.eu/News/Markets-Money/Rebounding-PVdemand-expected-in-Europe.

11. Dirk C. Jordan, Sarah RK (2012) Photovoltaic Degradation Rates - An Analytical Review. Journal Article NREL/JA-5200-51664 June.

12. Solar Panel Warranty Comparison, Energy Informative.

13. Andrew Moore (2009) The solar lifecycle test. ReNew Magazine, Alternative Technology Association pp 46-48.

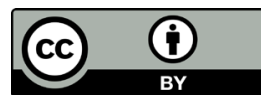

This work is licensed under Creative Commons Attribution 4.0 License DOI: 10.19080/IMST.2020.02.555583
14. Mibel Board of Regulators.

15. Energy Services Regulatory Authority.

16. Rede Energética Nacional.

17.EDP:http://www.edp.pt/pt/aedp/unidadesdenegocio/ producaodeelectricidade/Pages/ProducaoElectricidade.aspx

18. DGEG - Direcção-Geral de Energia e Geologia, www.dgge.pt/

\section{APREN. http://www.apren.pt/}

20. SPES - Sociedade Portuguesa de Energia Solar. http://www.spes.pt/

21.http://www.unep.ch/etb/publications/energySubsidies/ Energysubreport.pdf.

22.http:// www.unep.ch/etb/publications / EconInst/ econInstruOppChnaFin.pdf.

23. Implementation of a CirculAr economy Based on Recycled, reused and recovered Indium, Silicon and Silver materials for photovoltaic and other applications.

24.Zeng De-wn, Born, Manfred W, Karsten (2004) Pyrolysis of EVA and its application in recycling of photovoltaic modules. Journal of Environmental Sciences 16(6): 889-893.

25. Radziemska EK (2015) Recycling of Photovoltaic Solar Cells and Modules-The State-Of-Art. Saarbrucken. Alemanha: LAP LAMBERT Academic Publishing.

26. Jing Tao, Suiran Yu (2015) Review on feasible recycling pathways and technologies of solar photovoltaic modules. Solar Energy Materials \& Solar Cells 141: 108-124.

27. Frisson L, Lieten K, Bruton T, Declercq K, Szlufcik J, et al. (2000) Recent Improvments in Industrial PV Module Recycling. Europena Photovoltaic Solar Energy Conference, 16, 2000, Glasgow, Reino Unido.

28. Gustafsson AMK, Foreman MRSTJ, Ekberg C (2014) Recycling of high purity seleni-um from CIGS solar cellwaste materials. Waste Management 34(10): 1775-1782.

29. Veit HM (2005) Copper Recycling of Printed Circuit Board Scraps. 115f. Dissertation (Master in Engineering) - Postgraduate Program in Mining, Metallurgical and Materials Engineering, Federal University of Rio Grande do Sul, Porto Alegre.

30. Rojas CEB (2009) Jewelry Scrap Recycling for Gold and Silver Hydrometallurgical Recovery. Master's Dissertation UFMG.

- Quality Editorial service

- Swift Peer Review

- Reprints availability

- E-prints Service

- Manuscript Podcast for convenient understanding

- Global attainment for your research

- Manuscript accessibility in different formats

( Pdf, E-pub, Full Text, Audio)

- Unceasing customer service

Track the below URL for one-step submission https://juniperpublishers.com/online-submission.php 